\title{
Application of Project-based Learning in the Course of Electronic Technology Foundation
}

\author{
SUN Li-hui \\ College of Information and Control Engineering \\ Jilin Institute of Chemical Technology \\ Jilin, China \\ e-mail:sunlihui2000@126.com
}

\begin{abstract}
According to the "excellent engineers" plan for cultivating innovative applied talents demands, the Curriculum Reform which with application as the guide, with competency as the standard and with practice as the main line, is on the rise. Introducing project learning into the teaching of electronic technology foundation and starting teaching through the project, planning, project implementation and teaching evaluation and other aspects, the method is beneficial to cultivating students' autonomous inquiry, problem analysis and problem solving skills and the ability to apply theoretical knowledge to practice and innovation ability.
\end{abstract}

Keywords- Project-based Learning; electronic technology foundation; innovation ability

\section{INTRODUCTION}

With the rapid development of modern science and technology, social system, economic system and education system is changing constantly, thus society's need for high-quality technical personnel is also changing. In order to adapt to this kind of demand, the ability of people is also gradually improving and developing. In the modern society, people's ability requires three aspects, namely, professional ability, social ability and methods ability. Social ability and methods ability are the abilities to adapt to the society for students. To cultivate the abilities, the teacher should change the traditional teaching method, so as to adapt to the requirements that training students' to enhance their social abilities and methods abilities.

The course of electronic technology foundation is difficult relatively, because it requires the students to learn and master the basic theory and basic skills of electronic technology. Strong theoretical property, strong practicalness and applicability are the features of the course. But traditional teaching mode is theory before and then practice, the knowledge learning and skill training are separated completely. When students are learning theory knowledge, they don't know how to use the knowledge and they always stay in a passive learning state. So, in the course teaching, the Project-based Learning is introduced. through the leading and driving of the project, realize the integration of teaching, learning and doing, and also strengthen student the ability of applying theoretical knowledge into practice and ability of innovation.

\author{
YU Jun* \\ College of Information and Control Engineering \\ Jilin Institute of Chemical Technology \\ Jilin, China \\ e-mail:yujun0432@126.com
}

\section{PROJECT LEARNING}

\section{A. Contents of Project-based Learning}

Project-based Learning is a teaching activity by implementing a complete project, aims to integrate learning to the process of task completion, it can make students to study positively, to construct knowledge independently, and it also can make students to combine the theory learned in the classroom teaching, fully exploit students' creative potential and enhance students' comprehensive ability to solve practical problems. The main body of Project-based Learning is students, so it can make the students to complete independently in every part as far as possible, teachers only play the role of organization, coordination and guidance. A complete project of teaching content including project tasks, planning, project implementation, project inspection and project review, in addition to the project name, is made by students independently.

\section{B. The advantages of Project-based Learning}

Project-based Learning, whose most striking feature is taking project as the main line, taking teacher as dominant and taking student as the main body, it changes the past passive mode that teachers speak and students listen, it creates a new teaching mode of the students' active participation, autonomous collaboration, exploration and innovation. In the teaching activities, the teacher put the problems need to be solved or the need of task to be completed to students with the form of project. In the guide of teacher, the students themselves make plans together according to the practical work of the complete program in groups, and then complete the whole project together or division.

Project learning not only teaches students theoretical knowledge and operation skills, the more important is to develop their self-innovation abilities and realizes the integration of theory and practice in teaching. Project-Based Learning pays attention to the main body of students, it emphasize learning in the doing and doing in the learning. Through the complete of one and other project, students learn how to search information and design scheme, effectively mobilize students learning enthusiasm and initiative, and make the students change from "want me learn" to "I want to learn". In order to complete the project, 
students should make the solving method, so as to cultivate students' innovation ability. The difference between project- teaching and traditional teaching method is as shown in table 1 .

TABLE I. COMPARISON OF BETWEEN PROJECT-BASED LEARNING AND TRADITIONAL TEACHING METHOD

\begin{tabular}{|c|c|c|}
\hline Comparison of item & The traditional teaching & The Project-based Learning \\
\hline Instructional objectives & Impart knowledge and skills & $\begin{array}{l}\text { Autonomous learning new knowledge in } \\
\text { the process of solving the problem }\end{array}$ \\
\hline Instructional mode & $\begin{array}{l}\text { Mainly the teacher's teaching, students } \\
\text { passive learning }\end{array}$ & $\begin{array}{c}\text { Students learn actively under the guidance } \\
\text { of the teacher }\end{array}$ \\
\hline Means of communication & Unilateral, although interaction, but passive & $\begin{array}{l}\text { Multi-directional exchange, display } \\
\text { between team members and between } \\
\text { students and teachers }\end{array}$ \\
\hline Degree of participation & $\begin{array}{l}\text { Students follow the teacher's command, let } \\
\text { me learn }\end{array}$ & $\begin{array}{l}\text { The students make choices according to } \\
\text { their own interests, I want to learn }\end{array}$ \\
\hline motivator & $\begin{array}{c}\text { The external power is important, difficult } \\
\text { to sustain }\end{array}$ & Internal power fully to mobilze ,lasting \\
\hline characteristic & $\begin{array}{c}\text { The external power is important, difficult } \\
\text { to sustain }\end{array}$ & $\begin{array}{l}\text { The teacher according to the students' } \\
\text { advantages to carry out activities }\end{array}$ \\
\hline
\end{tabular}

\section{IMPLEMENTATION OF THE PROJECT TEACHING}

In the teaching of electronic technology foundation, the implementation of Project-Based Learning is divided into project design, grouping, making plans, analysis and discussion, project implementation and project evaluation, etc. Its implementation procedure flow chart is shown in figure 1.

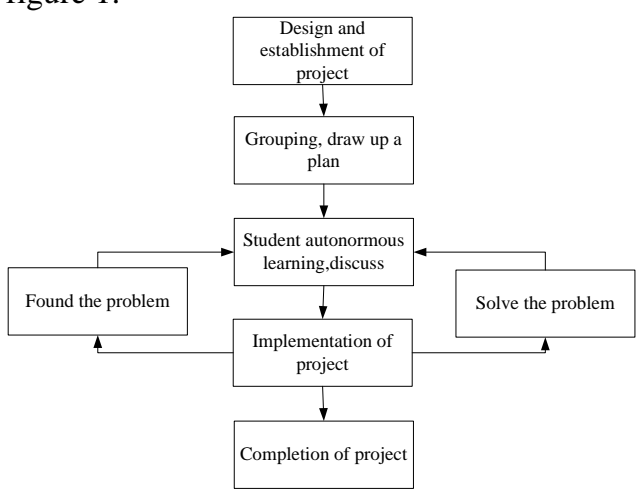

Fig1 the implementation procedure flow chart of Project-based Learning

\section{A. Establishment and design of project}

The key to a successful Project-Based Learning is to design a suitable job task. We should give full consideration to the following issues: (1) the activity of project whether to invoke the knowledge that students have learned? (2) The project activity how to help students learn the new knowledge independently? (3) The students are interested in the project or not?(4)how to strengthen the communication and cooperation among students?(5)How to help students connect learned knowledge with the real life?(6)the content of the project can help students enhance the self-confidence?

In the study" $§$ 9-3 combinational logic circuit design method"(Electronic technology foundation, higher education press),the designing task is: Designing a weight lifting voter, we can set $\mathrm{A}, \mathrm{B}$ two deputy referee and a referee C. Requiring when the referee's grade is valid and at least one deputy referee's grade is valid at the same time, the player's final result is valid. Because the circuit can be found everywhere in real life, students are very interested.

\section{B. Grouping Plan and Autonomous Learning}

The class is divided into several groups, and a group is about four students. The teacher should pay attention to the group of students, every group has good foundation, strong ability of students and relatively poor foundation of students.

According to the practical problems, the logic circuit diagrams that students designed are different. At first, instead of telling the students which one is the best, the teacher let them introduce the logic circuit that they designed. Some students' logic circuit diagrams are very reasonable, but many bugs are revealed when they are introducing their logic circuit diagrams. And some students' logic circuit diagrams are unreasonable, while their language is very concise and humorous. Some students also design the logic circuit diagrams, but they dare not to introduce, at this time, the teacher should guide them slowly into the roles and encourage them, so as to they can introduce their logic circuit diagrams completely. Secondly, when the introductions are done, the students all want to know that their designs are reasonable or not and want the teacher give evaluations, at this time, the teacher introduces the designing method of the logic circuit diagram. Finally, the students discuss their logic circuit diagrams and help each other to modify their logic circuit diagrams. In the process of designing circuit diagrams, the students use the brain and hand, learn autonomously and help each other, and with the help of teacher, they not only learn the knowledge, but also their language expression ability and communication ability are trained.

\section{Inspection and Evaluation}

After wiring, the students began to self-assessment and explain the practical application about them. In the process of work display, some students can visually demonstrate all 
the voting process of the sport competition, some students have this or that problem. Then teacher and students check circuit together and develop solutions. The final evaluation, teacher fully affirmed student achievements, then, the teacher detail introduces the combinational logic circuit design idea, the right design method and connection should be noticed, let students obtained system knowledge through the process of autonomous learning.

\section{Effects of the implementation of Project-based Learning}

Through the application and practice of Project-based Learning in the teaching of electronic technology basic course, students can participate the project actively, solving the problems of absent-minded and distraction in class. Students do in the learning and learn in the doing, learn to think and learn to find ways to solve the problems they meet, therefore fully taping the creative potential and enhancing the communication and cooperation ability.

Practice has proved that in the process of Project-based Learning, teachers change from imparter of knowledge to a consultant, or a mentor. So teachers must process professional theory and professional skills of a related project, which is suitable for use in teaching, must do lots of preparation in order to respond to various unknown problem for students, and must master each students' characteristic and put forward the corresponding teaching method, which is not only develops students' personalities, but also pays attention to the comprehensive balance, to stimulate the students' enthusiasm. The core of Project-based Learning is to complete a task finally, so the requirement to the school experiment equipment is much higher.

\section{E. Cautions of Project-based Learning}

1) Optimize project design and create efficient learning effects. If you want to get efficient learning effects in the teaching process, the selection of project must be adapted to the requirements that cooperation, arousing the students' consciousness easily and exerting the principal role of students.

2) Establish a good relationship between teachers and students, and improve the team cooperation spirit. In the teaching of the past, teachers are condescending and difficult to contact for students, but through the implementation of Project-based Learning in the teaching, it has established a good relationship between teachers and students. Teachers should respect students' design and results, try to know, understand and care about them, and attach the importance to students' needs.

3) Pay attention to cultivate students' independent and innovative ability. In the process of Project-based Learning that is implemented through groups. Every student should complete his task independently. In the process, students may have many doubts and questions. At this time, the teacher should give the help and guide them to learn, that is not only simply gives the answers ,but guides them to complete the tasks independently in the way of teaching them with the fishing.

\section{THE THINK DEEPLY ON PROJECT-BASED LEARNING}

It is undoubted that Project-based Learning is the embodiment of the advanced education system and the advanced education concept. And the method is benefit for improving students' professional ability, learning ability and social ability. But based on the present situation of our college, the foreign advanced teaching method is worth learning and reference, but it can't be copied and abused.

\section{A. The insufficient of teaching equipment constrains the development of Project-based Learning}

To cultivate students' professional knowledge and vocational skills rely on relatively perfect teaching equipments. On the other, Project-based Learning just puts forward very high demands on teaching equipment. Without enough equipment, Project-based Learning can only become a mere formality. It is very difficult for normal colleges to popularize because Project-based Learning requires large equipment in the process of implementation.

\section{B. Teachers factors have a significant impact on the} implementation of Project-based Learning

1) The relative lack of the number of teachers. Project-based Learning emphasizes students main roles and teachers leading roles in the teaching, but it does not relieve the teacher task. For the implementation of Project-based Learning, teachers not only should be proficient in each course, answer all kinds of problems at any time that students propose, but also should design and decide project, create learning situation, cultivate the atmosphere of collaborative learning and learn assessment, etc. In this way, the teacher task aggravates instead, and relatively the numbers of teachers will also appear more shortage.

2) The teachers' quality doesn't get the standards of double-teacher. To implement Project-based Learning, teachers must do a lot of preparatory work, in order to answer to various unknown problems for students, so as to make students behavior can be under the control of teachers. And teachers must be able to process professional theory and professional skills to complete the related project. And for now, many colleges and universities in our country the quality of teachers is not high to get the standards of double-teacher.

3) The change of teacher's role is difficult to adapt. The Project-based Learning is different from the traditional theory teaching, teachers are required to renew the teaching concept and role transformation. The teacher's role change form dominated by traditional teaching to the teaching guide, form "teaching" to "guide". The teachers had received a traditional education, and class used traditional teaching methods. Teachers adapt to the needs of the 
Project-based Learning method is easier said than done in a short time.

It can say, it is difficult to fully accept open teaching of Project-based Learning because of professional teacher quantity, teaching practices and teaching level. To really implement Project-based Learning and completion the task of teaching, teachers must pay more effort.

\section{The students directly affect the implementation of Project-based Learning}

In Project-based Learning, the implementation of the project take the student as the center, so teachers must mobilize student enthusiasm to participate in the Project-based Learning. If the enthusiasm of students is not mobilized, the Project-based Learning can not go on, the teaching effect of Project-based Learning may not be better than the traditional teaching.

Organization teaching in Project-based Learning, because it is the student autonomous learning mode, the student personality and ability obtain the full development, but it is also easy to appear the phenomenon of the polarization of students.

\section{CONCLUSION}

Project-based Learning method is used in electronic technology foundation, after several sessions of teaching practice, the method has been able to stimulate students learning enthusiasm and interest, to cultivate students rigorous work style and team spirit of unity and cooperation. At the same time, it can make students learn the core skills needed to work in the future, and lay a solid foundation for future work.

\section{ACKNOWLEDGMEN}

Project of research and practice of construction of groups of electronic basic courses supported by Jilin province higher education teaching research in 2012.t

\section{REFERENCE}

[1] Deng Zuo-jie,TAN Xiao-lan, MO Hai-yan. Practice and Study of Project Method [J].Journal of Hunan Institute of Engineering.2010,20 (3): 91-93

[2] Lin Zhuliang, Ma Shiping, Yang Jinhua. The application research of project-based learning in the electronic design courses $[\mathrm{J}]$. Experimental Technology and Management. 2009,26 (8): 114-116

[3] Yan yong, Lan Bo. Application of “Task-driven Teaching” method in Electric and Electronic Technology course [J]. Experimental Technology and Management .2012,29(9):163-166.

[4] Jonassen D,Davidson M. etal. Constructivism and Computer-Mediated Communication in Distance Education.[J]. The American Journal of Distance Education,1995,9(2):7-26.

[5] Wilson B.Metaphors for Instruction. Why We Talk About Learning Environments [J].Educational Technology.1995,21(9)25-30 